\title{
The growth and aflatoxin production of Aspergillus flavus strains on a cheese model system are influenced by physicochemical factors
}

\author{
Rocío Casquete, ${ }^{*} \dagger$ María José Benito, ${ }^{*}{ }^{1}$ María de Guía Córdoba, ${ }^{*} \dagger$ Santiago Ruiz-Moyano, ${ }^{*} \dagger$ \\ and Alberto Martín*† \\ *Nutrición y Bromatología, Escuela de Ingenierías Agrarias, Universidad de Extremadura, Avd. Adolfo Suárez s/n, 06007 Badajoz, Spain \\ †Instituto Universitario de Investigación en Recursos Agrarios, Avd. De la Investigación, Universidad de Extremadura, 06006 Badajoz, Spain
}

\begin{abstract}
Traditional cheeses may be contaminated by aflatoxin-producing Aspergillus flavus during the ripening process, which has not been sufficiently taken into account. The objectives of this study were to evaluate the influence of water activity $\left(\mathrm{a}_{\mathrm{w}}\right), \mathrm{pH}$, and temperature on the lag phases, growth, and aflatoxin production of 3 A. flavus strains (CQ7, CQ8, and CG103) on a cheese-based medium. The results showed that the behavior of $A$. flavus strains was influenced by $\mathrm{pH}, \mathrm{a}_{\mathrm{w}}$, and temperature conditions. The CQ7 strain showed the maximum growth at $\mathrm{pH} 5.5,0.99 \mathrm{a}_{\mathrm{w}}$, and $25^{\circ} \mathrm{C}$, whereas for CQ8 and CQ103 strains, no differences were obtained at $\mathrm{pH} 5.5$ and 6.0. In general, low $\mathrm{pH}$, $\mathrm{a}_{\mathrm{w}}$, and temperature values increased the latency times and decreased the growth rate and colony diameter, although $\mathrm{a}_{\mathrm{w}}$ and temperature were the most limiting factors. Maximum aflatoxin production on the cheesebased medium occurred at $\mathrm{pH} 5.0,0.95 \mathrm{a}_{\mathrm{w}}$, and 25 or $30^{\circ} \mathrm{C}$, depending on the strain. This study shows the effect of $\mathrm{pH}, \mathrm{a}_{\mathrm{w}}$, and temperature factors on growth and aflatoxin production of 3 aflatoxigenic A. flavus strains on a cheese-based medium. The findings may help to design control strategies during the cheesemaking process and storage, to prevent and avoid aflatoxin contamination by aflatoxigenic molds.
\end{abstract}

Key words: aflatoxin, Aspergillus flavus, growth, ripened cheese

\section{INTRODUCTION}

Mold spores are ubiquitous in nature, with the ability to survive stressful environment conditions and grow on many diverse substrates. Consequently, the contamination of cheese by yeast and molds can occur throughout the production, storage, and distribution chain.

Received March 13, 2017.

Accepted May 24, 2017.

${ }^{1}$ Corresponding author: mjbenito@unex.es
The raw materials, such as milk and coagulant, dairy utensils, and environment can act as potential vectors of microbial contamination (Irlinger et al., 2015). For instance, cardoon flowers (Cynara cardunculus L.), a vegetable coagulant typical of the Mediterranean area, constitute an important source of fungal contamination in certain artisanal cheese (Fernández-Salguero et al., 1999; Gómez et al., 2001; Tejada et al., 2008). Moreover, the technological processes applied during cheese manufacture, ripening, and storage [physicochemical (e.g., salting, temperature, water activity, $\mathrm{pH}$, and relative humidity) and biochemical (e.g., smoking, antimicrobial substances, and gas composition of package)] play a major role in the microbial dynamics (McSweeney et al., 2004; Almena-Aliste and Mietton, 2014; Montel et al., 2014).

Overall, molds are an important constituent of the secondary microbiota of cheese and their presence is acceptable, even necessary, due to their involvement in lipid and protein degradation that contribute to the sensorial properties of the final product, playing a key role in texture and flavor development (Molimard and Spinnler, 1996; Fox and McSweeney, 2004; Benkerroum, 2016). In certain cheeses, such as Camembert, Roquefort, or blue cheese, some species of molds, mainly Penicillium spp., are intentionally added as ripening starters (Ropars et al., 2012). However, the growth of some mold species can lead to deterioration of the product and production of toxic secondary metabolites called mycotoxins (O'Brien et al., 2004; Hymery et al., 2014). The mold most frequently identified in cheese is Penicillium spp., followed by Mucor spp. and Geotrichum candidum as well as 12 other fungal genera present to a lesser extent (Barrios et al., 1998). On the other hand, the contamination of Aspergillus spp. in cheese has been reported by several authors (Barrios et al., 1997; De Santi et al., 2010; Baranyi et al., 2015). Aflatoxins (AF) are highly toxic and carcinogenic mycotoxins produced by Aspergillus flavus and the less aggressive and less widely distributed Aspergillus parasiticus (Pitt and Hocking, 1999). Aflatoxins $\mathrm{B}_{1}$ and $\mathrm{B}_{2}$ are mainly pro- 
duced by $A$. flavus, whereas $A$. parasiticus can produce all $4 \mathrm{AF}\left(\mathrm{B}_{1}, \mathrm{~B}_{2}, \mathrm{G}_{1}\right.$, and $\left.\mathrm{G}_{2}\right)$. Aflatoxin $\mathrm{B}_{1}$ is produced in higher amounts than the other AF. Additionally, it is considered the most toxic natural compound, designated as a group 1 human carcinogen by the IARC (2012). These mycotoxins $\mathrm{AFB}_{1}, \mathrm{AFB}_{2}, \mathrm{AFG}_{1}$, and $\mathrm{AFG}_{2}$ have all been detected in cheeses (Taniwaki et al., 2001; Baranyi et al., 2015). In addition, sterigmatocystin, which is structurally related to AF because is produced by the same biochemical pathway from homologous structural gene, has been reported to occur in cheese linked to mold growth (Northolt et al., 1980; Sulyok et al., 2010). However, in general, few studies have documented the occurrence of AF by mold contamination, probably because mycotoxin studies have been more focused on economically important cheeses than on traditional raw milk cheeses, which are more prone to contamination by mycotoxigenic molds.

It is generally accepted that fungal growth and mycotoxin production in food is influenced by multiple factors, such as substrate composition, temperature, $\mathrm{a}_{\mathrm{w}}, \mathrm{pH}$, and microbial interactions (Magan and Aldred, 2007). The physicochemical characteristics of cheese are subject to changes during ripening, which influence the mycotoxin production. Aspergillus flavus grows and produces mycotoxins at a wide range of temperature and water activity $\left(\mathbf{a}_{\mathrm{w}}\right)$, although the ideal conditions are 28 to $30^{\circ} \mathrm{C}$, at high $\mathrm{a}_{\mathrm{w}}$ values (Schmidt-Heydt et al., 2009; Abdel-Hadi et al., 2012). The influence of these physicochemical factors on growth and mycotoxin production by A. flavus on cheese-based matrices has not yet been studied.

As a consequence of the intensive labor required, or even impossible processes, to eliminate mycotoxins from food matrix, preventive measures are considered to be the most practical and reasonable way to avoid mycotoxin contamination (Benkerroum, 2016). Therefore, understanding the influence of ecophysiological factors on $A$. flavus growth and $\mathrm{AF}$ production using a cheese model would provide valuable information for controlling their occurrence in the final product, thus minimizing the potential hazards associated with $\mathrm{AF}$ contamination of cheese due to mold growth.

The objective of this study was to evaluate the influence of $\mathrm{a}_{\mathrm{w}}, \mathrm{pH}$, and temperature on the lag phases before growth, growth, and AF production of A. flavus on a cheese-based medium.

\section{MATERIALS AND METHODS}

\section{Fungal Strains}

Three AF-producing Aspergillus strains, A. flavus CQ7, A. flavus CQ8, and A. flavus CQ103 (Fungi Cul- ture Collection of the Agricultural Engineer School, Extremadura University, Badajoz, Spain), previously isolated from C. cardunculus L., were used for this work. The spore suspensions were stored at $-80^{\circ} \mathrm{C}$ in glycerol solution ( $40 \% \mathrm{wt} / \mathrm{vol}$ ) before use.

\section{Preparation of Cheese Agar}

Cheese agar medium was used to determine the effect of $\mathrm{pH}, \mathrm{a}_{\mathrm{w}}$, and temperature on growth and $\mathrm{AF}$ production of the 3 A. flavus strains. The cheese-enriched medium was prepared as described by Gori et al. (2012), with modifications. Briefly, $200 \mathrm{~g} / \mathrm{L}$ of soft body matured cheese from raw ewe milk (Ordiales et al., 2013) was added to $400 \mathrm{~mL}$ of demineralized water and ground for 5 min using a hand blender. Trisodium citrate dihydrate $(12.5 \mathrm{~g} / \mathrm{L})$ and $\mathrm{NaCl}$ (40 g/L; Sigma-Aldrich, St. Louis, MO) were added, and the mixture was stirred vigorously on a magnetic stirrer and heated until boiling. Subsequently, $20 \mathrm{~g} / \mathrm{L}$ of Bacto agar (Pronadisa, Madrid, Spain) was added and the medium adjusted to $\mathrm{a}_{\mathrm{w}} 0.85,0.90,0.95$, and 0.99 by the addition of 286,193 , 101, and $0 \mathrm{~mL}$ of glycerol (Scharlab S.L., Barcelona, Spain) per liter of medium, respectively. Mineralized water was added to complete the volume to $1 \mathrm{~L}$ and the culture medium was sterilized by autoclaving at $121^{\circ} \mathrm{C}$ for $20 \mathrm{~min}$. Lactic acid, sterilized by filtration through a $0.2-\mu \mathrm{m}$ filter, was added to adjust the cheese medium to $\mathrm{pH} 5.0,5.5$, and 6.0, after autoclaving, when the temperature of the medium was $\sim 50^{\circ} \mathrm{C}$. Then, the cheese agar was immediately poured into Petri dishes and allowed to solidify at room temperature. The $\mathrm{a}_{\mathrm{w}}$ of the cheese agar medium was confirmed by using a Novasina LabMaster- $a_{w}$ meter (AG, Lachen, Switzerland).

\section{Inoculation of Cheese Agar}

For inoculum preparation, malt extract agar (Scharlab, Barcelona, Spain) was inoculated with the strains and incubated at $25^{\circ} \mathrm{C}$ for $7 \mathrm{~d}$. The spore suspension of each strain was collected by adding $10 \mathrm{~mL}$ of sterile aqueous $0.05 \mathrm{~mL} / 100 \mathrm{~mL}$ of Tween 80 (Scharlab) to each mold plate, followed by rubbing the surface with a glass rod. The suspension formed, was filtered through 2 layers of cheesecloth. The concentration of each spore suspension was quantified by using a microscope (Olympus CX 400, Tokyo, Japan) and Neubauer chamber. Two microliters of each spore suspension, adjusted to $10^{5}$ spores $/ \mathrm{mL}$ with sterile water, was inoculated onto cheese agar plates adjusted to the pre-determined $\mathrm{pH}$ and $\mathrm{a}_{\mathrm{w}}$ conditions, and incubated at various temperatures $\left(10,15,20,25\right.$, and $\left.30^{\circ} \mathrm{C}\right)$ to evaluate their influence on the growth of $A$. flavus and AF production. 


\section{Experimental Parameters}

Initial experiments were performed at 1 fixed temperature $\left(25^{\circ} \mathrm{C}\right)$, at $3 \mathrm{pH}(5.0,5.5$, and 6.0$)$ commonly encountered in cheese and cheese products. Afterward, the $\mathrm{pH}$ was fixed for further experiments to check the effect of $\mathrm{a}_{\mathrm{w}}(0.85,0.90,0.95$, and 0.99$)$ on growth and $\mathrm{AF}$ production at $25^{\circ} \mathrm{C}$ for $12 \mathrm{~d}$ after the end of the lag phase. Then, with $\mathrm{pH}$ and $\mathrm{a}_{\mathrm{w}}$ fixed, the experiment was checked at various temperatures $(10,15,20,25$, and $30^{\circ} \mathrm{C}$ ). For each experiment and condition, 2 biological replicates and 3 technical replicates were performed.

\section{Assessment of Growth and Lag Phase}

The diameter of the growing colonies of all replicates under all conditions was measured at 2 perpendicular directions every $48 \mathrm{~h}$ during the $12 \mathrm{~d}$ after the end of the lag phase. The average of both diameters was recorded as the growth measurement for each strain. Mean colony diameter $(\mathrm{mm})$ of each experiment and condition was plotted against incubation time (d) to establish growth curves for each fungal strain. The colony growth rate $[\mu(\mathrm{mm} / \mathrm{d})]$ was determined from the slope of the growth curve, whereas the lag phase $[\lambda(d)]$ was estimated by extrapolating the linear regression equation to the original inoculum size ( $\mu_{0}$ diameter, $\mathrm{mm}$ ) $\left(\lambda=\mu_{0} \pm \mathrm{b} / \mu\right.$, where $\mathrm{b}$ is the intercept of the original size).

\section{Preparation of Cheese-Based Agar Samples for AF Extraction}

Mycelia were collected at various time points, according to the first visual appearance of fungal colonies under the established $\mathrm{pH}, \mathrm{a}_{\mathrm{w}}$, and temperature conditions. Five agar plugs of $4 \mathrm{~mm}$ in diameter were removed from each mold colony culture every $48 \mathrm{~h}$ during $12 \mathrm{~d}$ after the end of the lag phase and placed in 2-mL microcentrifuge tubes. All replicates per treatment were collected and stored at $-20^{\circ} \mathrm{C}$, before extraction for $\mathrm{AF}$ quantification.

\section{AF Extraction}

Aflatoxins were extracted from the fungal mycelium by the quick, easy, cheap, effective, rugged, and safe (QuEChERS) procedure (Ferreira et al., 2012), with modifications. For this purpose, 2 agar plugs were placed in an extraction tube containing $200 \mathrm{mg}$ of $\mathrm{MgSO}_{4}$ and $50 \mathrm{mg}$ of NaOAc (both from Fisher Scientific, Madrid, Spain). Then, $1 \mathrm{~mL}$ of HPLC-grade acetonitrile (Fisher Scientific) was added and the mixture was shaken vigorously for $2 \mathrm{~min}$, followed by sonication for $20 \mathrm{~min}$, and then centrifuged at $14,000 \times g$ at $25^{\circ} \mathrm{C}$ for $1 \mathrm{~min}$. The supernatant was transferred to a clean tube containing $75 \mathrm{mg}$ of $\mathrm{MgSO}_{4}, 25 \mathrm{mg}$ of primary secondary amine (Sigma-Aldrich, St. Louis, MO), and $25 \mathrm{mg}$ of C18 (Scharlab), and homogenized for $1 \mathrm{~min}$. The mixture was centrifuged $\left(14,000 \times g, 25^{\circ} \mathrm{C}, 1 \mathrm{~min}\right)$ and $400 \mu \mathrm{L}$ of the supernatant was filtered through a $0.22-\mu \mathrm{m}$ pore size filter into vials for quantification.

The AF analysis was carried out using an Agilent 1100 Series HPLC system (Agilent Technologies, Santa Clara, CA) equipped with a diode array detector (Agilent G1315B) set at $360 \mathrm{~nm}$ and using a C18 HPLC column $(250 \times 4.6 \mathrm{~mm}, 5-\mu \mathrm{m}$ particle size; Supelco, Bellefonte, PA). The mobile phase used for the separation contained HPLC grade water (solvent A) and HPLC grade acetonitrile (solvent B), run in a gradient mode set from $15 \% \mathrm{~B}$ at initial to $100 \% \mathrm{~B}$ at $30 \mathrm{~min}$. A 3-min period was necessary for column equilibration. All solvents used were purchased from Thermo Fisher Scientific (Runcorn, UK). The injection volume was 25 $\mu \mathrm{L}$ and the flow rate was $1 \mathrm{~mL} / \mathrm{min}$ for all the experiments. Calibrations were carried out for each AF using standards purchased from Sigma-Aldrich.

\section{Statistical Analysis}

The physicochemical and growth parameters and toxin production were compared during the sampling time using a 1-way ANOVA. The means were separated by Tukey's honest significant difference test $(P<0.05)$ using SPSS for Windows 21.0 (SPSS Inc., Chicago, IL).

\section{RESULTS AND DISCUSSION}

\section{Effect of $\mathrm{pH}, \mathrm{a}_{\mathrm{w}}$, and Temperature on the Growth of A. flavus}

The effects of the evaluated physicochemical parameters on the colony diameter and growth parameters of the $3 \mathrm{AF}$-producing A. flavus strains isolated from C. cardunculus L. flowers, are presented in Figure 1 and Table 1, respectively. At $0.99 \mathrm{a}_{\mathrm{w}}$ at $25^{\circ} \mathrm{C}$, the $\mathrm{pH}$ affected colony growth and was evidently strain dependent. Among the strains, CQ7 presented better ability to grow at lower $\mathrm{pH}$ (5.0 and 5.5), displaying the lowest colony diameter and growth rate, whereas it had the longest lag phase $(P<0.05)$ at $\mathrm{pH}$ 6.0. In contrast, $A$. flavus CQ8 and CQ103 showed similar behavior at the $3 \mathrm{pH}$ tested, with significantly less growth at $\mathrm{pH} 5.0(P$ $<0.05$; Figure 1). For both CQ8 and CG103, although the lag phase was not affected by the $\mathrm{pH}$, a significant reduction in growth rate and colony diameter was observed at pH 5.0 (Table 1). Kosegarten et al. (2017) studied the influence of various factors on the growth 
of $A$. flavus, observing that the optimum growth rate occurred between $\mathrm{pH} 3.5$ to 6.0, although they showed that the growth of $A$. flavus was less affected by $\mathrm{pH}$ than other environmental factors. These studies are in line with the results obtained in the present work.

Regarding the influence of $\mathrm{a}_{\mathrm{w}}$ on growth at $\mathrm{pH} 5.0$ at $25^{\circ} \mathrm{C}$, the $3 \mathrm{~A}$. flavus strains were not able to grow at $0.85 \mathrm{a}_{\mathrm{w}}$. Pitt and Miscamble (1995) determined that a minimum 0.80 to $0.83 \mathrm{a}_{\mathrm{w}}$ was necessary to support the growth of A. flavus. However, other authors shown a lack of or marginal growth at $0.90 \mathrm{a}_{\mathrm{w}}$ at $25^{\circ} \mathrm{C}$ (Medina et al., 2015; Lahouar et al., 2016). As shown in Figure 1, CQ7 did not grow at $0.90 \mathrm{a}_{\mathrm{w}}$, whereas CQ8 and CQ103 showed the minimum mean values of growth rate and colony diameter (Table 1 ). At 0.95 or 0.99 $\mathrm{a}_{\mathrm{w}}$, the growth was more favorable for the 3 strains, although they presented significant differences at the optimal $\mathrm{a}_{\mathrm{w}}$ (Figure 1; Table 1). Among the strains, CQ7 showed the best ability to grow at both $\mathrm{a}_{\mathrm{w}}$, with a higher colony diameter and growth rate and a shorter lag phase under both conditions. Although CQ8 presented a lower growth capacity than CQ7, both exhibited similar growth tendency, with the highest colony diameter, growth rate, and lowest lag phase at 0.99 $\mathrm{a}_{\mathrm{w}}$. In contrast, CQ103 showed the maximum colony diameter and growth rate at $0.95 \mathrm{a}_{\mathrm{w}}(P<0.05$; Figure 1 ; Table 1 ). It is well known that $A$. flavus is highly sensitive at $\sim 0.90 \mathrm{a}_{\mathrm{w}}$ at $25^{\circ} \mathrm{C}$ and exhibits optimum growth between 0.95 to $0.99 \mathrm{a}_{\mathrm{w}}$. Overall, our results are in line with those described by other authors for this species on other media or in food matrix models. Lahouar et al. (2016) observed that a minimum $0.91 \mathrm{a}_{\mathrm{w}}$ was required for mycelial growth at $25^{\circ} \mathrm{C}$, whereas Mousa et al. (2011), using a paddy grains model, showed that a minimum $0.86 \mathrm{a}_{\mathrm{w}}$ allowed the growth of A. flavus. Conversely, Abdel-Hadi et al. (2012) observed that the optimum growth of $A$. flavus occurred at $0.99 \mathrm{a}_{\mathrm{w}}$ at 30 to $35^{\circ} \mathrm{C}$ during storage. More recently, Peromingo et al. (2016), using a meat model system, and Gallo et al. (2016), using an almond medium, showed that the most favorable conditions were at $\sim 0.95 \mathrm{a}_{\mathrm{w}}$ at 25 and $28^{\circ} \mathrm{C}$, respectively.

The effect of temperature was determined at values ranging from 10 to $30^{\circ} \mathrm{C}$, at $0.95 \mathrm{a}_{\mathrm{w}}, \mathrm{pH}$ 5.0. The highest colony diameter and best growth parameters were observed at $25^{\circ} \mathrm{C}$ for $\mathrm{CQ7}$, whereas CQ8 and CQ103 reached their maximum growth at $30^{\circ} \mathrm{C}$ (Figure 1 ; Table 1). Temperatures below $20^{\circ} \mathrm{C}$ significantly influenced the colony diameter and growth rate of the 3 strains. At $10^{\circ} \mathrm{C}$, mold growth was not detected for any strains and at 15 and $20^{\circ} \mathrm{C}$, a noticeable effect was observed, with colony diameter below $30 \mathrm{~mm}$ at $12 \mathrm{~d}$ of growth (Figure 1; Table 1). These results agree with those obtained by Gallo et al. (2016), who observed that the ideal temperature for the growth of $A$. flavus on an almond medium at $0.96 \mathrm{a}_{\mathrm{w}}$ was at $28^{\circ} \mathrm{C}$ when compared with 20 and $37^{\circ} \mathrm{C}$. Likewise, other authors have reported that the optimum growth conditions for this species, on various substrates, occur at 25 to $30^{\circ} \mathrm{C}$, at $\sim 0.95 \mathrm{a}_{\mathrm{w}}$ (Lahouar et al., 2016; Peromingo et al., 2016; Kosegarten et al., 2017). In contrast, temperatures below $20^{\circ} \mathrm{C}$ have widely demonstrated to considerably reduce $A$. flavus growth, with a growth limit $\sim 10^{\circ} \mathrm{C}$ (Sautour et al., 2002; Abdel-Hadi et al., 2012; Astoreca et al., 2012; Medina et al., 2015; Peromingo et al., 2016).

The behavior of the 3 A. flavus strains studied under the various $\mathrm{pH}, \mathrm{a}_{\mathrm{w}}$, and temperature conditions, was confirmed by the growth parameters including growth rate $(\mu)$, lag phase $(\lambda)$, and maximum growth $\left(y_{\max }\right.$; Table 1). The CQ7 strain showed the maximum growth at $\mathrm{pH} 5.5,0.99 \mathrm{a}_{\mathrm{w}}, 25^{\circ} \mathrm{C}$, whereas for the other 2 strains, no differences were observed at $\mathrm{pH} 5.5$ and 6.0. Figure 2 shows an example of the effect of the various conditions studied on the colony growth of CQ8. In general, low $\mathrm{pH}, \mathrm{a}_{\mathrm{w}}$, and temperature values increased the latency times and had a greater effect on the growth rate and colony diameter, although $\mathrm{a}_{\mathrm{w}}$ and temperature were the most limiting factors (Figure 1; Table 1), corroborating similar, previous studies (Schmidt-Heydt et al., 2008; Kosegarten et al., 2017). The slight divergences found among the literature and between our study and other works concerning the specific critical values of $\mathrm{pH}, \mathrm{a}_{\mathrm{w}}$, and temperature, depend on intrinsic and extrinsic factors, such as the strains studied, nutrient composition of the medium, and methods used.

\section{Effect of $\mathrm{pH}, \mathrm{a}_{\mathrm{w}}$, and Temperature on AF Production by A. flavus}

Table 2 shows the effect of $\mathrm{pH}$ variation on AF production by the $A$. flavus strains on the cheese model medium. At the $3 \mathrm{pH}$ tested, at $0.99 \mathrm{a}_{\mathrm{w}}$ and $25^{\circ} \mathrm{C}$, only $\mathrm{AFB}_{1}$ was found, with values ranged from no detection to $7.46 \mu \mathrm{g} / \mathrm{cm}^{2}$. In general, the production of $\mathrm{AFB}_{1}$ was significantly affected by the $\mathrm{pH}$ and growth time $(P<$ $0.05)$. The 3 strains displayed dissimilar AF production patterns during the growth period. The CQ7 showed a relatively lower capacity to produce $\mathrm{AFB}_{1}$, with only slight production detected at $\mathrm{pH} 5.0$ at $10 \mathrm{~d}$. The CQ7 produced the maximum $2.73 \mu \mathrm{g} / \mathrm{cm}^{2}$ of $\mathrm{AFB}_{1}$ at $\mathrm{pH}$ 5.0 at $12 \mathrm{~d}$, whereas production occurred earlier for the other 2 strains (d 4). The CQ103 started to produce $\mathrm{AFB}_{1}$ at $\mathrm{pH} 5.5$ at $4 \mathrm{~d}$ and at $\mathrm{pH} 5.0$ at $\mathrm{d} 6$, with similar mean values, ranging from 0.81 to $1.88 \mu \mathrm{g} / \mathrm{cm}^{2}$, at both $\mathrm{pH}$ at $\mathrm{d} 6$, whereas no production was detected at $\mathrm{pH}$ 6.0. The most versatile strain was CQ8, which produced $\mathrm{AFB}_{1}$ under all $\mathrm{pH}$ conditions after d 4, showing a significantly greater amount of the toxin at higher $\mathrm{pH}$ 


\section{Aspergillus flavus CQ7}

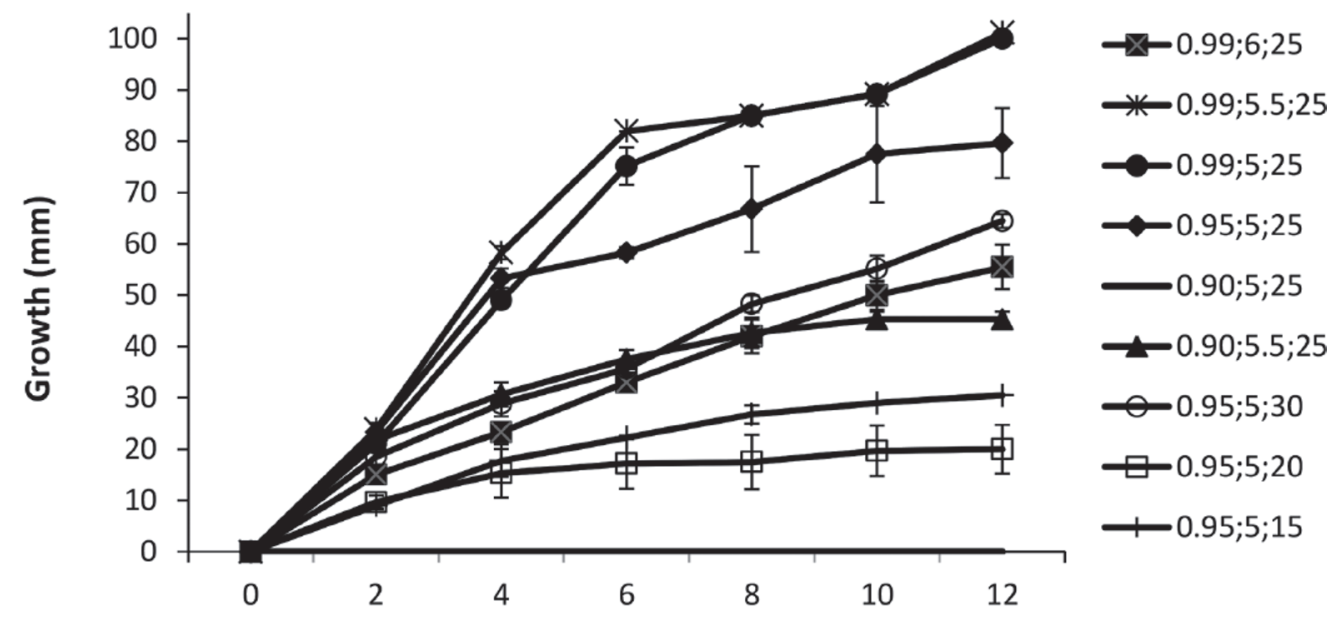

\section{Aspergillus flavus CQ8}

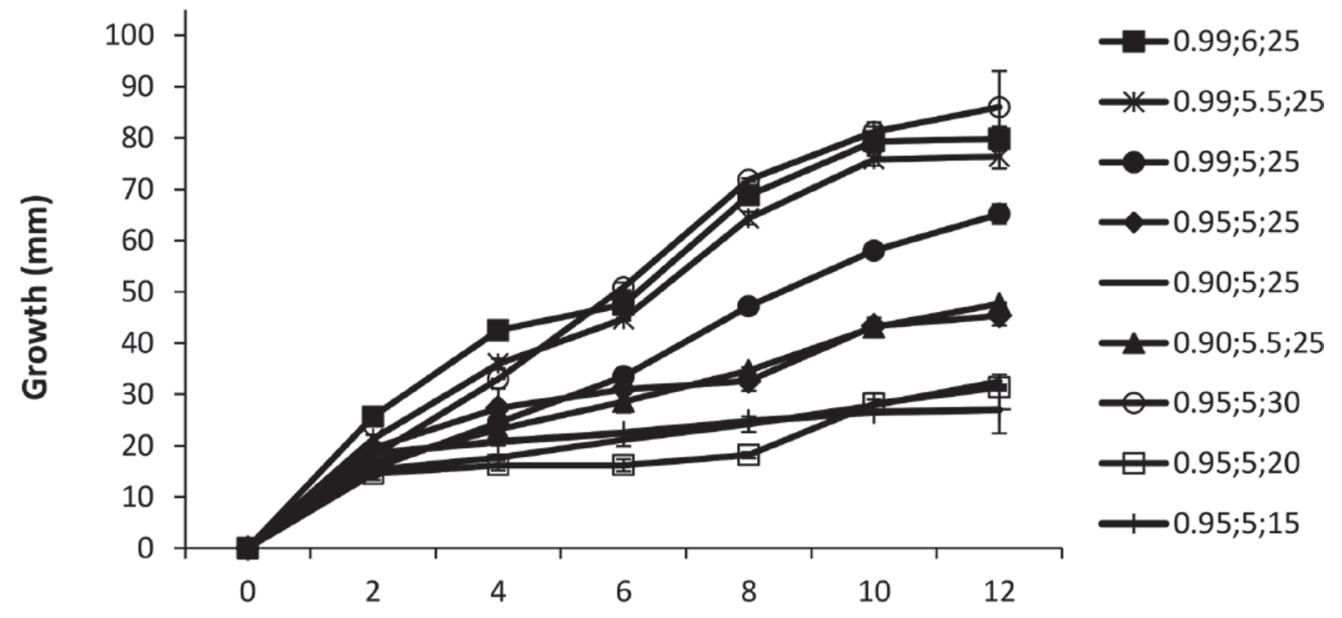

\section{Aspergillus flavus CQ103}

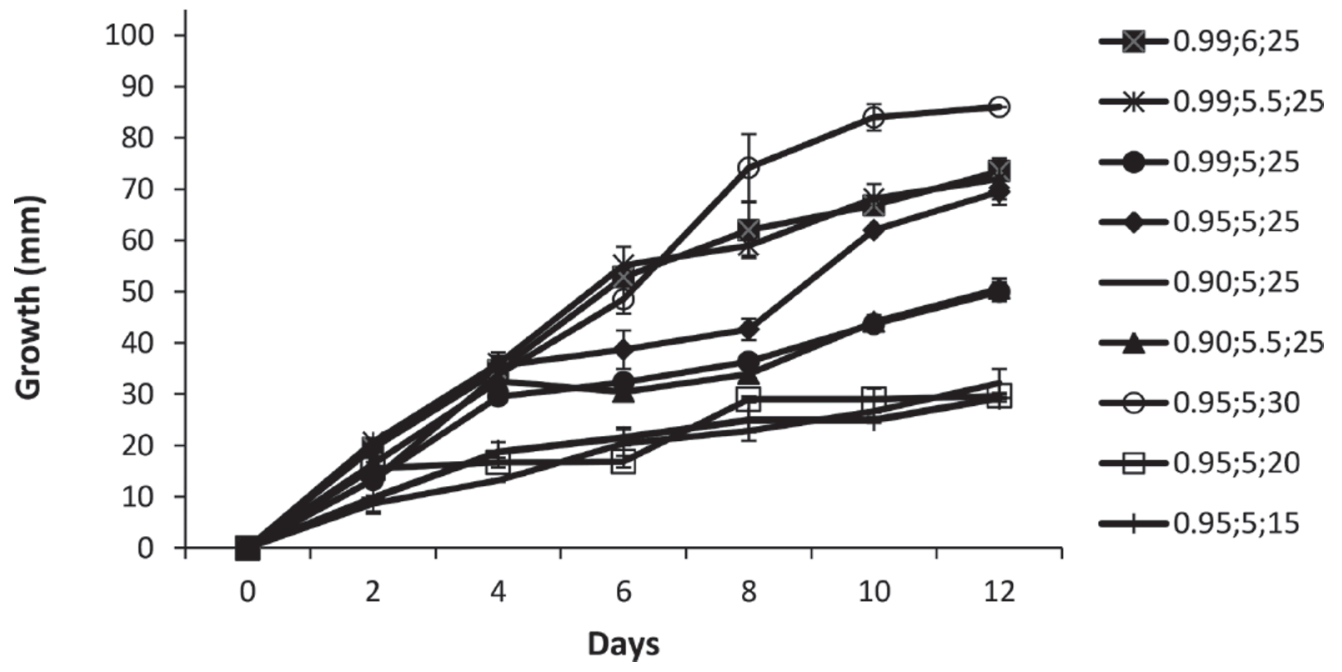

Figure 1. Effect of water activity $(0.90,0.95$, and 0.99$), \mathrm{pH}(5.0,5.5$, and 6.0$)$, and temperature $\left(15,20,25\right.$, and $\left.30^{\circ} \mathrm{C}\right)$ on radial growth $(\mathrm{mm})$ of 3 Aspergillus flavus strains (CQ7, CQ8, and CQ103) on a cheese-based medium for $12 \mathrm{~d}$ after the end of the lag phase. 
Table 1. Effect of $\mathrm{pH}$, water activity $\left(\mathrm{a}_{\mathrm{w}}\right)$, and temperature $(\mathrm{T})$ on growth parameters [growth rates $(\mu)$, lag phase $(\lambda)$, and maximum growth (ymax)] of 3 Aspergillus flavus strains on a cheese-based medium

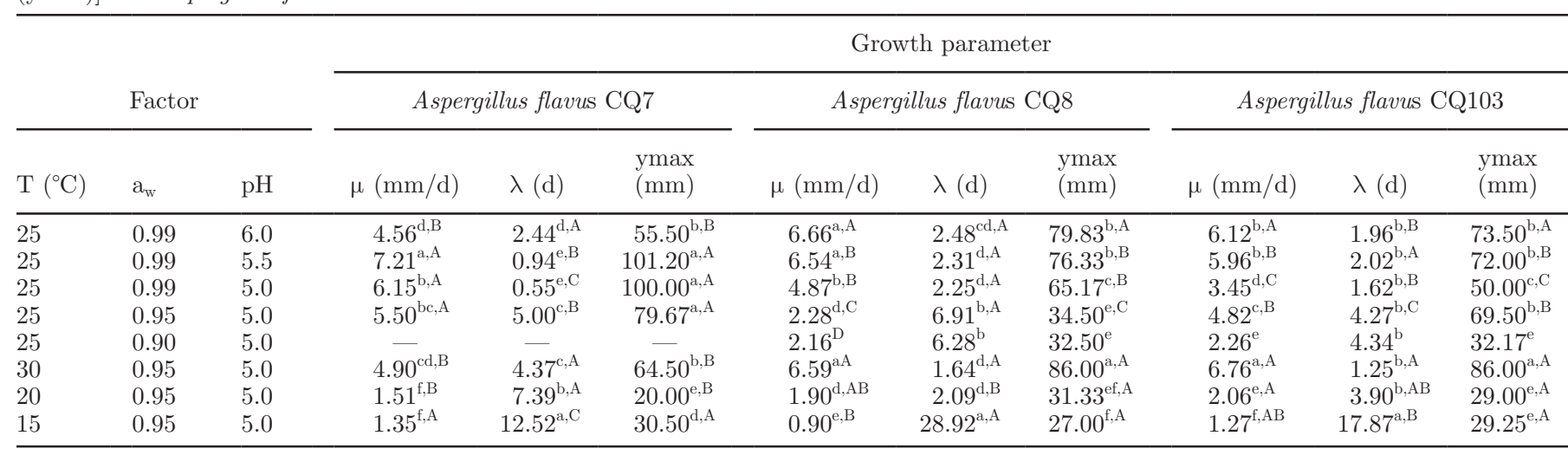

\footnotetext{
${ }^{\mathrm{a}-\mathrm{f}}$ Values with different lowercase superscripts are significantly different $(P<0.05)$ between conditions within the same parameter and strain.
}

${ }^{\mathrm{A}-\mathrm{D}}$ Values with different uppercase superscripts are significantly different $(P<0.05)$ between parameters within the same condition.

(5.5 and 6.0 vs. 5.0) throughout the growth time, except at $\mathrm{d} 12$, where there were not statistical differences between $\mathrm{pH}$. It is well known that $\mathrm{pH}$ can influence the regulation of the pathways involved in mycotoxin biosynthesis by various mold species including Aspergillus spp. (Keller et al., 1997; Schmidt-Heydt et al., 2008). In general, the production of mycotoxins is usually higher at low pH. Keller et al. (1997) reported a higher AF production by $A$. parasiticus at $\mathrm{pH} 4.0$ to 6.0 than at $\mathrm{pH} 7.0$ and 8.0, with a noticeable reduction in the accumulation of $\mathrm{AF}$ and a delay in the expression level of the homologous sterigmatocystin/AF structural gene with increasing $\mathrm{pH}$. However, the optimal $\mathrm{pH}$ for $\mathrm{AF}$ production may vary depending on the strain and medium composition. For example, in 2 A. flavus strains, Patel et al. (2014) showed increased $\mathrm{AFB}_{1}$ production at $\mathrm{pH} \sim 6.5$ at $27^{\circ} \mathrm{C}$ compared with acid $\mathrm{pH}$, with slight differences between strains. In our work, although the $\mathrm{pH}$ tested were in close proximity, discrete patterns in $\mathrm{AFB}_{1}$ production were evident (Table 2).

A prominent effect of $\mathrm{a}_{\mathrm{w}}$ variation was observed at $\mathrm{pH} 5.0$ at $25^{\circ} \mathrm{C}$ on $\mathrm{AF}$ production in all the strains tested (Figure 3; Table 2). The 2 extreme values of 0.90 and $0.99 \mathrm{a}_{\mathrm{w}}$ were stress conditions for AF production by the 3 strains. At $0.90 \mathrm{a}_{\mathrm{w}}$, the strains CQ7 and CQ103 were not able to produce AF, whereas CQ8 showed slight accumulations of $0.66,1.91,0.99$, and $1.09 \mu \mathrm{g} /$ $\mathrm{cm}^{2}$ at $6,8,10$, and $12 \mathrm{~d}$. At $0.99 \mathrm{a}_{\mathrm{w}}$, a certain $\mathrm{AFB}_{1}$ production was accumulated by the 3 strains, in the range of 0.87 to $3.42 \mu \mathrm{g} / \mathrm{cm}^{2}$. During growth at 0.99 $\mathrm{a}_{\mathrm{w}}$, CQ8 began to accumulate AF from d 4, which was earlier than CQ103 and CQ7, which began at d 6 and 10, respectively. The maximum AF accumulation was evident at $0.95 \mathrm{a}_{\mathrm{w}}$. At this $\mathrm{a}_{\mathrm{w}}$, all the strains produced $\mathrm{AFB}_{1}$ and $\mathrm{AFB}_{2}$ but at different levels during the growth period (Figure 3). Overall, similar amounts of
$\mathrm{AFB}_{1}$ were produced by the 3 strains, with $\sim 40 \mu \mathrm{g} /$ $\mathrm{cm}^{2}$ after d 6 of growth, except CQ7, which reached $\sim 70 \mu \mathrm{g} / \mathrm{cm}^{2}$ at d 4 (Figure 3). Regarding $\mathrm{AFB}_{2}$ production, discrete differences in the amounts produced were observed between strains. The CQ8 and CQ103 strains showed a limited capacity to produce this AF, with levels below $5 \mu \mathrm{g} / \mathrm{cm}^{2}$ detected, whereas, CQ7 showed a similar ability to produce both AF. Production of these $2 \mathrm{AF}$ at the same ratio is unusual in A. flavus because, generally, this species is considered to produce mainly $\mathrm{AFB}_{1}$ (Gallo et al., 2016; Lahouar et al., 2016). The AF production was strongly affected by the $a_{w}$, with optimum production at $0.95 \mathrm{a}_{\mathrm{w}}$ on the cheese-based medium. These results, in general, concur with those reported in the literature for A. flavus. Astoreca et al. (2014) concluded that AF production may occur at 0.86 to $0.98 \mathrm{a}_{\mathrm{w}}$. Although $\sim 0.83 \mathrm{a}_{\mathrm{w}}$ could be considered the lower limit for production, maximum production is reported to occur from 0.95 to $0.99 \mathrm{a}_{\mathrm{w}}$ at $\sim 25$ to $30^{\circ} \mathrm{C}$ (Giorni et al., 2011; Astoreca et al., 2014; Gallo et al., 2016; Peromingo et al., 2016). However, in the current study, a significant decrease in AF production was detected between 0.95 and $0.99 \mathrm{a}_{\mathrm{w}}$ that may be due to the important influence of the medium characteristics and also the strains studied in the determination of optimal conditions (Klich, 2007).

The influence of temperature variation on $\mathrm{AF}$ production was also evaluated in the range 15 to $30^{\circ} \mathrm{C}$ (Figure 3). As observed for $\mathrm{a}_{\mathrm{w}}$, a noticeable effect of temperature variation was observed among the 3 strains assayed. These 2 abiotic factors have shown to have a more pronounced effect than $\mathrm{pH}$ on the regulation of mycotoxin biosynthesis genes in Aspergillus spp. (Schmidt-Heydt et al., 2008). In this study, A. flavus strains did not produce $\mathrm{AF}$ at $15^{\circ} \mathrm{C}$, whereas at $20^{\circ} \mathrm{C}$, a relatively low amount was detected and the accumula- 


\section{A) Day 8}

\section{Temperature $25^{\circ} \mathrm{C} \mathrm{a} \mathrm{a}_{\mathrm{w}} 0.99$}

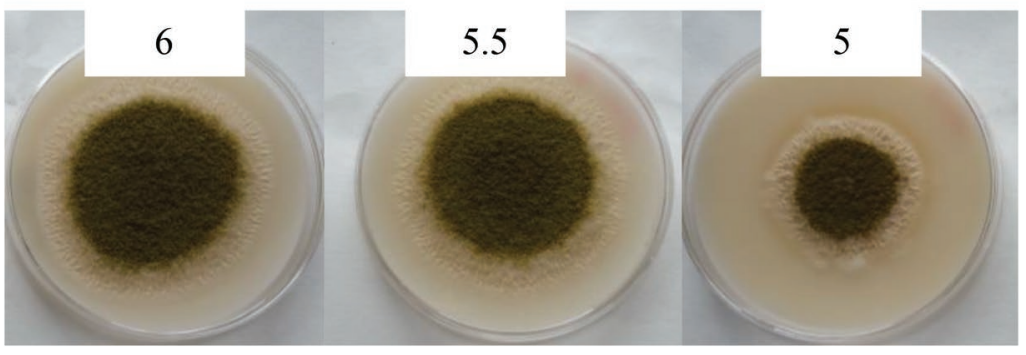

\section{B) Day 8}

Temperature $25^{\circ} \mathrm{C} \mathrm{pH} 5$

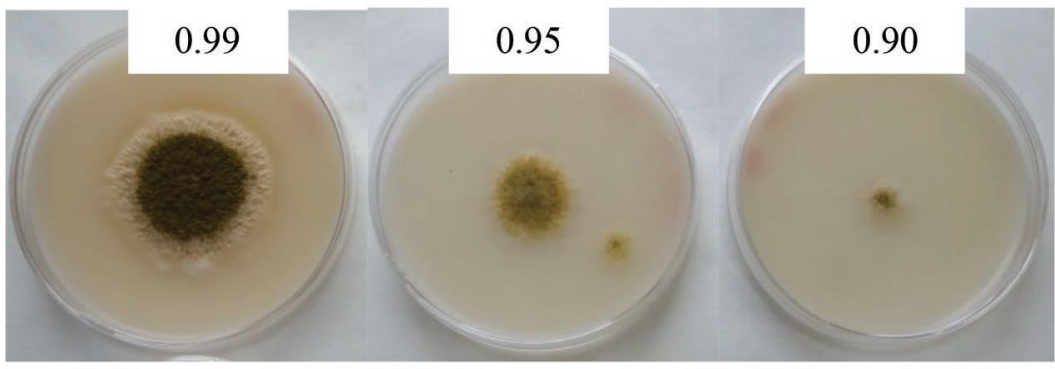

\section{C) Day 8}

\section{$\mathrm{pH} 5 \mathrm{a}_{\mathrm{w}} 0.95$}

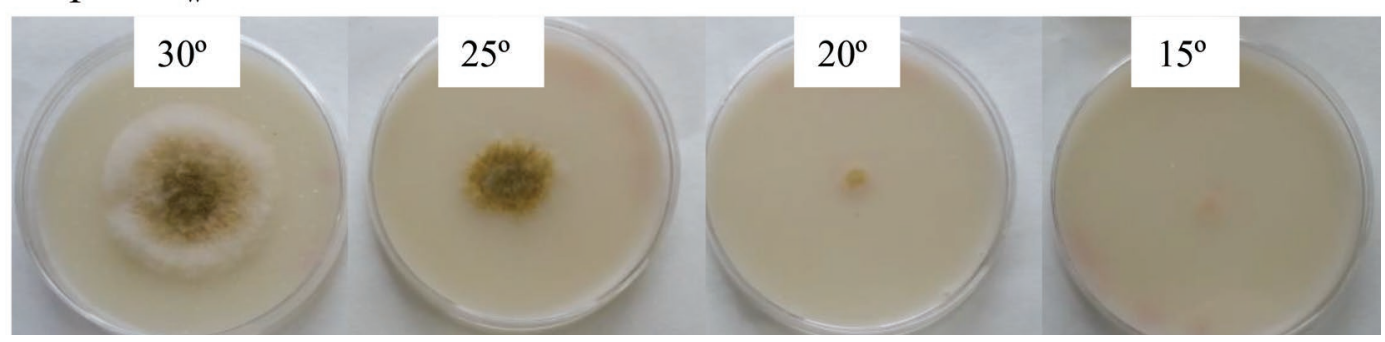

Figure 2. Colony growth of Aspergillus flavus CQ8 on a cheese-based medium under various conditions. (A) pH: 6.0, 5.5, and 5.0 at 8 d after the end of the lag phase; (B) 0.99, 0.95, and 0.90 water activity $\left(\mathrm{a}_{\mathrm{w}}\right)$ at $8 \mathrm{~d}$ after the end of the lag phase; (C) incubation temperature: 15,20 , 25 , and $30^{\circ} \mathrm{C}$ at $8 \mathrm{~d}$ after the end of the lag phase. Color version available online.

Table 2. Effect of $\mathrm{pH}(5.0,5.5$, and 6.0$)$ at 0.99 water activity and $25^{\circ} \mathrm{C}$ on aflatoxin production $\left(\mu \mathrm{g} / \mathrm{cm}^{2}\right)$ by 3 Aspergillus flavus strains for 12 $\mathrm{d}$ after the end of the lag phase

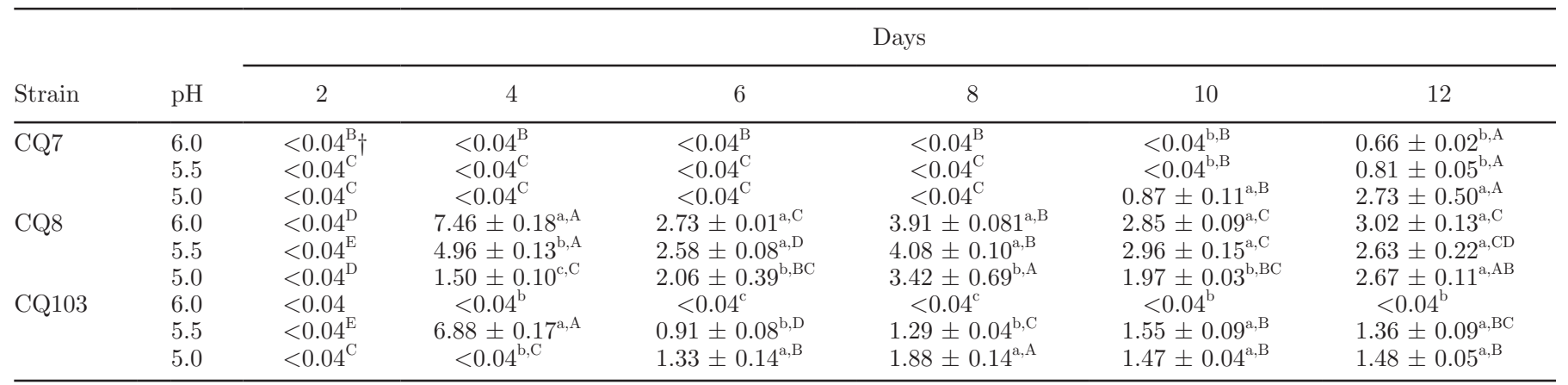

\footnotetext{
${ }^{\mathrm{a}-\mathrm{c}}$ Values with different lowercase superscripts are significantly different $(P<0.05)$ between conditions with equal day and strain.

${ }^{\mathrm{A}-\mathrm{E}}$ Values with different uppercase superscripts are significantly different $(P<0.05)$ between days for one condition.
}

$\dagger$ For 1-way ANOVA, the samples under the limit of detection were set at 0 . 


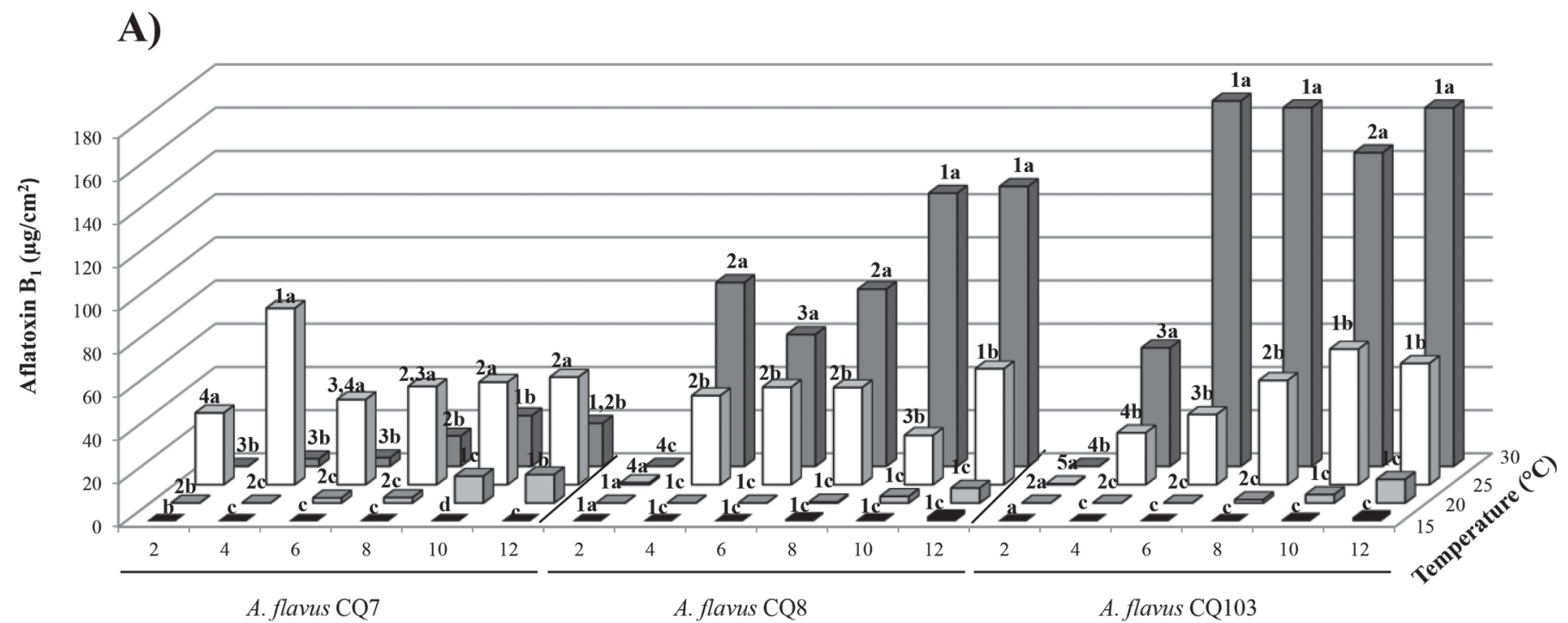

B)

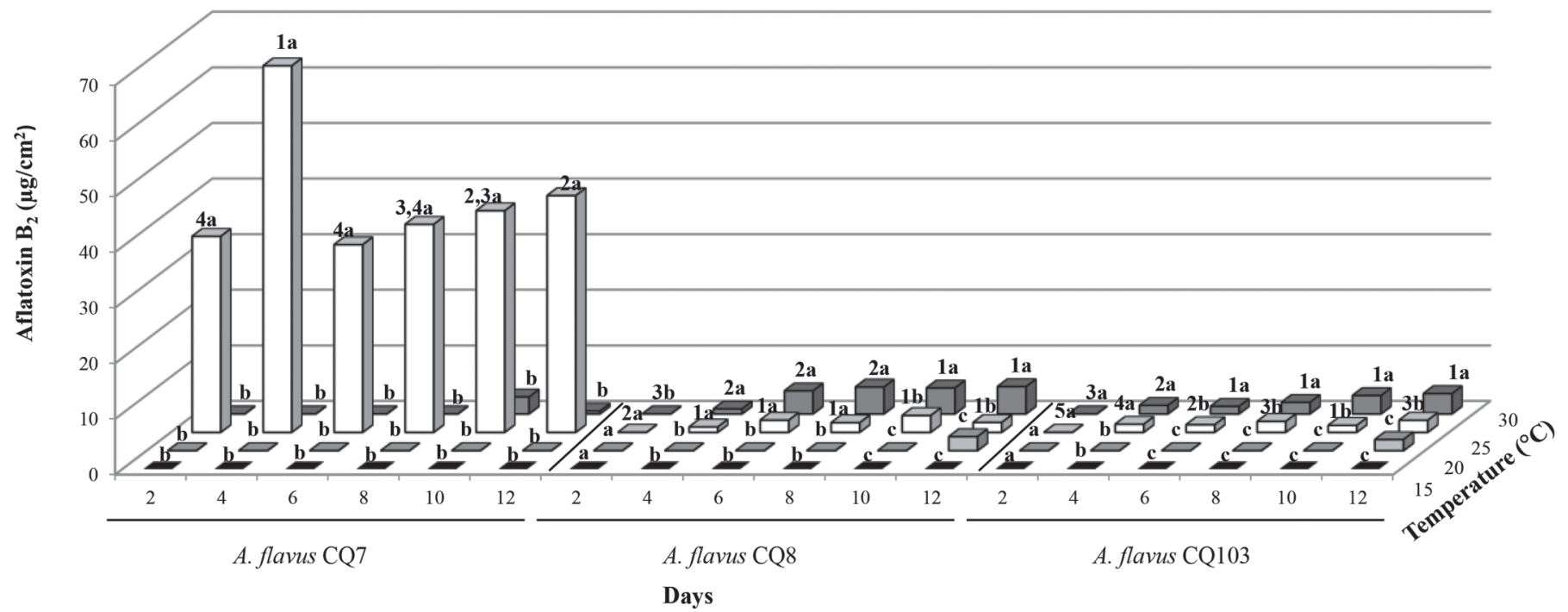

Figure 3. Effect of temperature variation $\left(15,20,25\right.$, and $\left.30^{\circ} \mathrm{C}\right)$ on aflatoxin production by Aspergillus flavus strains $\left[(\mathrm{A})\right.$ aflatoxin $\mathrm{B}_{1}$, (B) aflatoxin $\mathrm{B}_{2}$ ] on a cheese-based medium at 0.95 water activity and $\mathrm{pH} 5$ for $12 \mathrm{~d}$ after the end of the lag phase. Values with different letters $(\mathrm{a}-\mathrm{d})$ are significantly different $(P<0.05)$ between conditions with equal day and strain. Values with different numbers $(1-5)$ are significantly different $(P<0.05)$ between days for one condition.

tion was delayed compared with the values obtained at 25 and $30^{\circ} \mathrm{C}$. At these higher temperatures $(25$ and $30^{\circ} \mathrm{C}$ ), a significant increase in $\mathrm{AFB}_{1}$ and $\mathrm{AFB}_{2}$ was observed for the 3 strains, with production after $2 \mathrm{~d}$ of growth, in all instances. The strains CQ8 and CQ103 showed a similar pattern of AF accumulation with the temperature variation. Both strains reached optimum production at $30^{\circ} \mathrm{C}$, where at $12 \mathrm{~d}$ of growth, $\sim 120$ and $160 \mu \mathrm{g} / \mathrm{cm}^{2}$ of $\mathrm{AFB}_{1}$ was recorded for CQ8 and CQ103, respectively. On the contrary, CQ7 presented a significantly higher $\mathrm{AFB}_{1}$ and $\mathrm{AFB}_{2}$ production at $25^{\circ} \mathrm{C}$, with $\sim 40 \mu \mathrm{g} / \mathrm{cm}^{2}$ for both AF at $12 \mathrm{~d}$ of growth. Previous studies on this species have reported that optimum AF production at 25 to $30^{\circ} \mathrm{C}$, regardless of the medium used, whereas an important decrease in production is usually found below $20^{\circ} \mathrm{C}$ or above $35^{\circ} \mathrm{C}$ (Giorni et al., 2007; O'Brian et al., 2007; Astoreca et al., 2014; Medina et al., 2015; Gallo et al., 2016; Peromingo et al., 2016).

To the best of the authors' knowledge, this is the first published work to document the effect of various abiotic factors on A. flavus in a cheese model system. Overall, the maximum AF production on the cheese- 
based medium was obtained at $\mathrm{pH} 5.0,0.95 \mathrm{a}_{\mathrm{w}}$, at 25 or $30^{\circ} \mathrm{C}$, depending on the strain. These conditions were, in general, slightly lower than those obtained for optimal growth. Moreover, a minor variation in the conditions implied an important decrease in AF accumulation, despite considerable growth (Figures 1 and 3). Therefore, $\mathrm{AF}$ production occurred within a narrow range when compared with the mold growth. Similar findings were found by Abdel-Hadi et al. (2012) and Gallo et al. (2016) on synthetic yeast extract-sucrose medium and an almond system model, respectively. The production of AF by A. flavus in response to abiotic factors has been addressed in previous works but the optimal conditions reported for growth and AF production are not always consistent (Schmidt-Heydt et al., 2009; Abdel-Hadi et al., 2012). Abiotic conditions that are slightly lower than those considered optimal for growth have been shown to lead to high amounts of AF, whereas more extreme stress conditions result in inhibitory production (Schmidt-Heydt et al., 2009; Abdel-Hadi et al., 2012). In addition, the biosynthesis of AF can be switched on when the growth is high and the medium is depleted in nutrients (Schmidt-Heydt et al., 2008). The influence of abiotic factors on regulating the biosynthesis of genes involved in secondary metabolite production has not yet been correlated with the primary metabolism for growth (Schmidt-Heydt et al., 2008; Magan and Medina, 2016). Understanding the ecological conditions for growth and AF production of A. flavus in a cheese model is decisive to adopting preventive actions in the dairy industry aimed at eliminating AF occurrence.

\section{CONCLUSIONS}

The current study showed the effect of environmental factors, including $\mathrm{pH}, \mathrm{a}_{\mathrm{w}}$, and temperature, on the growth and aflatoxin production of 3 aflatoxigenic $A$. flavus strains on a cheese-based medium. The results described provide valuable knowledge about the optimal and limiting conditions for growth and AF production that may help researchers design and implement effective control strategies to avoid contamination by aflatoxigenic molds during the manufacture and storage of cheese.

\section{ACKNOWLEDGMENTS}

This work was funded by the Spanish Ministry of Economy (Madrid, AGL2013-45729-P). The authors are grateful to M. Cabrero and J. Hernández Barreto (Escuela de Ingenierías Agrarias, Universidad de Extremadura) for technical assistance.

\section{REFERENCES}

Abdel-Hadi, A., M. Schmidt-Heydt, R. Parra, R. Geisen, and N. Magan. 2012. A systems approach to model the relationship between aflatoxin gene cluster expression, environmental factors, growth and toxin production by Aspergillus flavus. J. R. Soc. Interface 9:757-767.

Almena-Aliste, M., and B. Mietton. 2014. Cheese classification, characterization and categorization: A global perspective. Pages 39-71 in Cheese and Microbes. C. W. Donnelly, ed. ASM Press, Washington, DC.

Astoreca, A., G. Vaamonde, A. Dalcero, S. Marin, and S. Ramos. 2014. Abiotic factors and their interactions influence on the coproduction of aflatoxin $\mathrm{B}_{1}$ and cyclopiazonic acid by Aspergillus flavus isolated from corn. Food Microbiol. 38:276-283.

Astoreca, A., G. Vaamonde, A. Dalcero, A. J. Ramos, and S. Marín. 2012. Modelling the effect of temperature and water activity of Aspergillus flavus isolates from corn. Int. J. Food Microbiol. 156:60-67.

Baranyi, N., D. J. Despot, A. Palágyi, N. Kiss, S. Kocsubé, A. Szekeres, A. Kecskeméti, O. Bencsik, C. Vágvölgyi, M. Š. Klarić, and J. Varga. 2015. Identification of Aspergillus species in Central Europe able to produce G-type aflatoxins. Acta Biol. Hung. $66: 339-347$.

Barrios, M. J., L. M. Medina, M. G. Cordoba, and R. Jordano. 1997. Aflatoxin-producing strains of Aspergillus flavus isolated from cheese. J. Food Prot. 60:192-194.

Barrios, M. J., L. M. Medina, M. C. López, and R. Jordano. 1998. Fungal biota isolated from Spanish cheeses. J. Food Saf. 18:151-157.

Benkerroum, N. 2016. Mycotoxins in dairy products: A review. Int. Dairy J. 62:63-75.

De Santi, M., M. Sisti, E. Barbieri, G. Piccoli, G. Brandi, and V. Stocchi. 2010. A combined morphologic and molecular approach for characterizing fungal microflora from a traditional Italian cheese (Fossa cheese). Int. Dairy J. 20:465-471.

Fernández-Salguero, J., E. Sánchez, R. Gómez, C. Mata, M. Vioque, and L. Tejada. 1999. Preliminary study of microbiological quality of cardoons Cynara L. used in the manufacture of traditional cheeses. Milchwissenschaft 54:688-690.

Ferreira, I., J. O. Fernandes, and S. C. Cunha. 2012. Optimization and validation of a method based in a QuEChERS procedure and gas chromatography-mass spectrometry for the determination of multi-mycotoxins in popcorn. Food Contr. 27:188-193.

Fox, P. F., and P. L. H. McSweeney. 2004. Cheese: An overview. Pages 1-18 in Cheese: Chemistry, Physics and Microbiology. General Aspects. Vol. 1. P. F. Fox, P. L. McSweeney, T. M. Cogan, and T. P. Guinee, ed. Elsevier Academic Press, London, UK.

Gallo, A., M. Solfrizzo, F. Epifani, G. Panzarini, and G. Perrone. 2016. Effect of temperature and water activity on gene expression and aflatoxin biosynthesis in Aspergillus flavus on almond medium. Int. J. Food Microbiol. 217:162-169.

Giorni, P., N. Magan, A. Pietri, and P. Battilani. 2011. Growth and aflatoxin production of an Italian strain of Aspergillus flavus: Influence of ecological factors and nutritional substrates. World Mycotoxin J. 4:425-432.

Giorni, P., N. Magan, A. Pietri, T. Bertuzzi, and P. Battilani. 2007. Studies on Aspergillus section Flavi isolated from maize in northern Italy. Int. J. Food Microbiol. 113:330-338.

Gómez, R., E. Sanchez, M. Vioque, J. Ferreira, L. Tejada, and J. Fernández-Salguero. 2001. Microbiological characteristics of ewes' milk cheese manufactured using aqueous extracts of flowers from various species of cardoon Cynara L. Milchwissenschaft 56:16-19.

Gori, K., L. M. Sørensen, M. A. Petersen, L. Jespersen, and N. Arneborg. 2012. Debaryomyces hansenii strains differ in their production of flavor compounds in a cheese-surface model. MicrobiologyOpen 1:161-168.

Hymery, N., V. Vasseur, M. Coton, J. Mounier, J. L. Jany, G. Barbier, and E. Coton. 2014. Filamentous fungi and mycotoxins in cheese: A review. Compr. Rev. Food Sci. Food Saf. 13:437-456. 
IARC (International Agency for Research on Cancer). 2012. Agents classified by the IARC monographs. Vol. 1-104. Accessed Apr. 15, 2016. http://monographs.iarc.fr/ENG/Classification/index.php.

Irlinger, F., S. Layec, S. Hélinck, and E. Dugat-Bony. 2015. Cheese rind microbial communities: Diversity, composition and origin. FEMS Microbiol. Lett. 362:1-11.

Keller, N. P., C. Nesbitt, B. Sarr, T. D. Phillips, and G. B. Burow. 1997. $\mathrm{pH}$ regulation of sterigmatocystin and aflatoxin biosynthesis in Aspergillus spp. Phytopathology 87:643-648.

Klich, M. A. 2007. Environmental and developmental factors influencing aflatoxin production by Aspergillus flavus and Aspergillus parasiticus. Mycoscience 48:71-80.

Kosegarten, C. E., N. Ramírez-Corona, E. Mani-López, E. Palou, and A. López-Malo. 2017. Description of Aspergillus flavus growth under the influence of different factors (water activity, incubation temperature, protein and fat concentration, $\mathrm{pH}$, and cinnamon essential oil concentration) by kinetic, probability of growth, and time-to-detection models. Int. J. Food Microbiol. 240:115-123.

Lahouar, A., S. Marin, A. Crespo-Sempere, S. Saïd, and V. Sanchis. 2016. Effects of temperature, water activity and incubation time on fungal growth and aflatoxin B1 production by toxinogenic $A s-$ pergillus flavus isolates on sorghum seeds. Rev. Argent. Microbiol. 48:78-85

Magan, N., and D. Aldred. 2007. Why do fungi produce mycotoxins? Pages 121-133 in Food Mycology: A Multifaceted Approach to Fungi and Food. J. Dijksterhuis and R. A. Samson, ed. CRC Press, Boca Raton, FL.

Magan, N., and A. Medina. 2016. Integrating gene expression, ecology and mycotoxin production by Fusarium and Aspergillus species in relation to interacting environmental factors. World Mycotoxin J. 9:673-684

McSweeney, P. L. H., G. Ottogalli, and P. F. Fox. 2004. Diversity of cheese varieties: An overview. Pages 1-22 in Cheese: Chemistry, Physics and Microbiology. Vol 2. Major Cheese Groups. P. F. Fox, P. L. H. McSweeney, T. M. Cogan, and T. P. Guinee, ed. Elsevier Academic Press, San Diego, CA.

Medina, A., M. Schmidt-Heydt, A. Rodríguez, R. Parra, R. Geisen, and N. Magan. 2015. Impacts of environmental stress on growth, secondary metabolite biosynthetic gene clusters and metabolite production of xerotolerant/xerophilic fungi. Curr. Genet. 61:325334.

Molimard, P., and H. E. Spinnler. 1996. Review: Compounds involved in the flavor of surface mold-ripened cheeses: Origins and properties. J. Dairy Sci. 79:169-184.

Montel, M. C. S. Buchin, A. Mallet, C. Delbes-Paus, D. A. Vuitton, N. Desmasures, and F. Berthier. 2014. Traditional cheeses: Rich and diverse microbiota with associated benefits. Int. J. Food Microbiol. 177:136-154

Mousa, W., F. M. Ghazali, S. Jinap, H. M. Ghazali, and S. Radu. 2011. Modelling the effect of water activity and temperature on growth rate and aflatoxin production by two isolates of Aspergillus flavus on paddy. J. Appl. Microbiol. 111:1262-1274.

Northolt, M. D., H. P. Van Egmond, P. Soentoro, and E. Deijll. 1980. Fungal growth and the presence of sterigmatocystin in hard cheese. J. Assoc. Off. Anal. Chem. 63:115-119.
O'Brian, G. R., D. R. Georgianna, J. R. Wilkinson, J. Yu, H. K Abbas, D. Bhatnagar, T. E. Cleveland, W. Nierman, and G. A. Payne. 2007. The effect of elevated temperature on gene transcription and aflatoxin biosynthesis. Mycologia 99:232-239.

O'Brien, N. M., T. P. O'Connor, J. O'Callaghan, and A. D. W. Dobson. 2004. Toxins in cheese biogenic amines and mycotoxins in cheese: Chemistry, physics and microbiology. Chapter 19 in General Aspects. Vol. 1. 3rd ed. P. F. Fox, T. Guinee, T. Cogan, and P. McSweeney, ed. Elsevier Applied Science, Amsterdam, the Netherlands.

Ordiales, E. M. J. Benito, A. Martín, R. Casquete, M. J. Serradilla and M. G. Córdoba. 2013. Bacterial communities of the traditional raw ewe's milk cheese "Torta del Casar" made without the addition of a starter. Food Contr. 33:448-454.

Patel, T. K., R. Anand, A. P. Singh, J. Shankar, and B. N. Tiwary 2014. Evaluation of aflatoxin B1 biosynthesis in A. flavus isolates from central India and identification of atoxigenic isolates. Biotechnol. Bioprocess Eng.; BBE 19:1105-1113.

Peromingo, B., A. Rodríguez, V. Bernáldez, J. Delgado, and M. Rodríguez. 2016. Effect of temperature and water activity on growth and aflatoxin production by Aspergillus flavus and Aspergillus parasiticus on cured meat model systems. Meat Sci. 122:76-83.

Pitt, J. I., and A. D. Hocking. 1999. Fungi and Food Spoilage, 2nd ed. Aspen Publishers Inc., Frederick, MD.

Pitt, J. I., and B. F. Miscamble. 1995. Water relations of Aspergillus flavus and closely related species. J. Food Prot. 58:86-90.

Ropars, J., C. Cruaud, S. Lacoste, and J. Dupont. 2012. A taxonomic and ecological overview of cheese fungi. Int. J. Food Microbiol. 155:199-210.

Sautour, M., C. S. Mansur, C. Divies, M. Bensoussan, and P. Dantigny. 2002. Comparison of the effects of temperature and water activity on growth rate of food spoilage moulds. J. Ind. Microbiol Biotechnol. 28:311-315.

Schmidt-Heydt, M., A. Abdel-Hadi, N. Magan, and R. Geisen. 2009. Complex regulation of the aflatoxin biosynthesis gene cluster of Aspergillus flavus in relation to various combinations of water activity and temperature. Int. J. Food Microbiol. 135:231-237.

Schmidt-Heydt, M., N. Magan, and R. Geisen. 2008. Stress induction of mycotoxin biosynthesis genes by abiotic factors. FEMS Microbiol. Lett. 284:142-149.

Sulyok, M., R. Krska, and R. Schuhmacher. 2010. Application of an LC-MS/MS based multi-mycotoxin method for the semi-quantitative determination of mycotoxins occurring in different types of food infected by moulds. Food Chem. 119:408-416.

Taniwaki, M. H., A. D. Hocking, J. I. Pitt, and G. H. Fleet. 2001 Growth of fungi and mycotoxin production on cheese under modified atmospheres. Int. J. Food Microbiol. 68:125-133.

Tejada, L., A. Abellan, F. Prados, and J. Cayuela. 2008. Compositional characteristics of Murcia al Vino goat's cheese made with calf rennet and plant coagulant. Int. J. Dairy Technol. 61:119-125. 